\title{
ANALISIS IMPLEMENTASI KEBIJAKAN TUNJANGAN PROFESI GURU DI SMA NEGERI 1 PALU
}

\author{
$\underline{\text { Idris Ade }}$ \\ Idrus
}

\author{
SMA Negeri 1 Palu, Widyaiswara LPMP Sulawesi Tengah \\ Email : roredonggala@yahoo.com, Hp. 085241021350
}

\begin{abstract}
Abstrak
Penelitian ini mengkaji; (1) Bagaimana implementasi kebijakan pemberian tunjangan profesi guru di SMA Negeri 1 Palu? dan (2) Faktor-faktor apakah yang menghambat implementasi kebijakan tunjangan profesi guru.? Tujuan penelitian ini yaitu: (1) Menganalisis implementasi kebijakan pemberian tunjangan profesi guru di SMA Negeri 1 Palu dan (2) Menganalisis faktor penghambat Implementasi kebijakan tunjangan profesi guru SMA Negeri 1 Palu. Penelitian ini menggunakan pendekatan deskriptif-kualitatif. Pengumpulan data dilakukan dengan cara wawancara, observasi, dan dokumentasi. Teknik analisis data menggunakan teknik model interaktif Miles dan Huberman. Hasil penelitian menyimpulkan (1) Secara keseluruhan implementasi kebijakan tunjangan profesi guru di SMAN 1 berjalan baik sesuai model Edward III yakni komunikasi, sumber daya, disposisi, dan struktur birokrasi. Akan tetapi, ada satu indikator pada pada variabel sumber daya yakni staf pengelola belum mampu menjabarkan petunjuk kepala sekolah terkait pengelolaan administrasi kebijakan tunjangan profesi guru dan satu indikator terkait struktur birokrasi yakni kecepatan dan ketepatan pengiriman berkas masih perlu ditingkatkan; (2) Faktor penghambat implementasi kebijakan tunjangan profesi guru adalah kecenderungan staf pengelola menunggu perintah dan kurang inisiatif.
\end{abstract}

Kata Kunci: Implementasi Kebijakan, Tunjangan Profesi Guru 


\begin{abstract}
This study examines: (1) How to implement policies to provide benefits in the teaching profession SMA Negeri 1 Pal u? (2) whether the factors that hinder the implementation of the policy benefits of the teaching profession? The purpose of this study are: (1) to analyze the implementation of policies to provide benefits in the teaching profession SMAN 1 Palu and (2) analyze the factors inhibiting teachers professional allowance policy implementation SMA Negeri 1 Palu. This study used a qualitative descriptive approach. The data was collected by interview, observation, and documentation. Analysis using techniques Miles and Huberman interactive model. The study concluded (1) Overall policy implementation allowance teacher at SMAN 1 Palu went well according to the model of Edward III namely communication, resources, disposition, and bureaucratic structures. However, there is an indicator on the resource variables that management staff has not been able to outline the principals instructions related to administration policy benefits of the teaching profession and related indicators of the bureaucratic structure of the file transfer speed and accuracy could be improved, (2) factors inhibiting the implementation of the policy benefits of the teaching profession is the tendency of managers to wait staff command and lack of initiative.
\end{abstract}

Keywords : Policy Implementation, Teacher Professional Allowance

\title{
Pendahuluan
}

Mengurus pendidikan tidak mudah karena permasalahan dalam dunia pendidikan tergolong kompleks. Akan tetapi satu hal dapat dipastikan bahwa pendidikan bukan hanya persoalan gedung sekolah, kurikulum, dan beasiswa atau bantuan sekolah (dana). Oleh karena itu, kebijakan pemerintah tidak hanya menyentuh aspek fisikal dan dana melainkan juga terkait dengan regulasi. Regulasi yang digulirkan pemerintah juga tidak hanya berkaitan dengan fisik melainkan berkaitan pula dengan pemberdayaan guru karena disadari sepenuhnya bahwa betapapun lengkap sarana pendidikan, dana yang mencukupi, input (siswa) yang berkualitas, pemimpin (kepala sekolah) yang profesional, staf administrasi (tata usaha sekolah) yang handal, 
akan tetapi tanpa guru yang kompeten dan profesional, maka tetap tidak akan menghasilkan mutu pendidikan yang optimal karena menurut Khoiri (2010: 35) "tidak terbantahkan bahwa guru merupakan bagian terpenting dalam proses belajar mengajar.

Dalam setiap upaya peningkatan kualitas pendidikan di tanah air, tidak dapat dilepaskan dari berbagai hal yang berkaitan dengan eksistensi guru itu sendiri." Sementara itu, Alma (2008: 123) menyatakan "guru merupakan kunci keberhasilan sebuah lembaga pendidikan. Guru adalah sales agent dari lembaga pendidikan." Bukan itu saja dalam perspektif lebih luas, Asmani (2010: 2011) menyatakan "guru adalah aktor utama perubahan di tengah masyarakat."

Mengacu uraian di atas, maka tidak berlebihan bahkan sangat tepat jika kemudian pemerintah mengeluarkan Undang-undang Guru Nomor 14 Tahun 2005 tentang Guru dan Dosen. Salah satu muatan yang paling mendapat perhatian dalam UU Guru dan Dosen adalah sertifikasi. Pada pasal 1 ayat 11 UU No 14/2005 dinyatakan "sertifikasi adalah proses pemberian sertifikat pendidik untuk guru dan dosen." Implikasi bagi guru yang telah memperoleh sertifikat pendidik dinyatakan lebih lanjut dalam UU RI No. 14/2005 pasal 16 bahwa "pemerintah akan memberikan tunjangan profesi kepada guru yang besarnya setara dengan 1 (satu) kali gaji pokok pada tingkat, masa kerja dan kualifikasi yang sama." Jadi, guru yang telah mendapat sertifikat pendidik akan memperoleh tunjangan profesi yakni tunjangan yang diberikan kepada guru yang memiliki sertifikat pendidik sebagai penghargaan atas profesionalitasnya (PP No. 41/2009 pasal 1 ayat 4).

Berdasarkan uraian tersebut, maka dapat diformulasikan beberapa permasalahan yang perlu dikaji mendalam dalam 
penelitian ini, sebagai berikut: (1) Bagaimana implementasi kebijakan pemberian tunjangan profesi guru di SMA Negeri 1 Palu? (2) Faktor-faktor apakah yang menghambat Implementasi kebijakan tunjangan profesi guru SMA Negeri 1 Palu? Sementara itu yang menjadi tujuan penelitian adalah (1) Menganalisis implementasi kebijakan pemberian tunjangan profesi guru di SMA Negeri 1 Palu, (2) menganalisis faktor penghambat Implementasi kebijakan tunjangan profesi guru SMA Negeri 1 Palu.

Berdasarkan rumusan masalah, maka tujuan penelitian dapat diuraikan sebagai berikut: (1) Menganalisis implementasi kebijakan pemberian tunjangan profesi guru di SMA Negeri 1 Palu; (2) Menganalisis kinerja guru SMA Negeri 1 Palu setelah memperoleh tunjangan profesi guru; dan (3) Menganalisis faktor penghambat Implementasi kebijakan tunjangan profesi guru untuk meningkatkan kinerja guru SMA Negeri 1 Palu.

\section{Kebijakan Publik}

Secara etimologis istilah yang memiliki akar kata bijak ini, oleh Dunn (2003: 10) dijelaskan bahwa "kebijakan (politik) berasal dari bahasa Yunani yaitu "polis" (negara) dan akhirnya ke dalam bahasa Inggris "policy" (kebijaksanaan) dan "politics." Dari perspektif terminologis, kebijakan telah banyak diberikan batasan dan definisi. Titmuss dalam Suharto (2005: 7) menjelaskan "kebijakan adalah prinsip-prinsip yang mengatur tindakan yang diarahkan kepada tujuan-tujuan tertentu." Senada dengan pengertian tersebut, Suharto (2005: 7) menyatakan pula pemikirannya "kebijakan adalah prinsip atau cara bertindak yang dipilih untuk mengarahkan pengambilan keputusan."

Kebijakan tentu tidak sama dengan keputusan. Secara spesifik perbedaan antara kebijakan dan keputusan dikemukakan oleh Budiman Rusli dalam Kadji (2008: 6). "Ada tiga perbedaan 
mendasar antara kebijakan dengan keputusan, yakni; (1) ruang lingkup kebijakan jauh lebih besar daripada keputusan; (2) pemahaman terhadap kebijakan yang lebih besar menerlukan penelahan yang mendalam terhadap keputusan; (3) kebijakan biasanya mencakup upaya penelusuran interaksi yang berlangsung diantara begitu banyak individu, kelompok dan organisasi."

Kebijakan berhubungan erat dengan pilihan-pilihan bahkan kebijakan itu sendiri merupakan bentuk lain dari pilihan. Dunn dalam Wibawa (1994: 50) menyatakan "kebijakan adalah serangkaian pilihan tindakan pemerintah (termasuk pilihan untuk tidak bertindak) guna menjawab tantangan yang menyangkut kehidupan masyarakat." Budiman (1997: 89) menyatakan "kebijakan adalah keputusan-keputusan publik yang diambil oleh negara dan dilaksanakan oleh aparat birokrasi." Secara eksplisit dinyatakan kebijakan harus ditempatkan dalam kerangka adanya kewenangan dari pihak yang memutuskan kebijakan yakni pemerintah atau birokrasi. Uraian tersebut mengantar untuk masuk menelaah kebijakan publik.

Menurut Kadji (2008: 1) "kebijakan publik dalam perspektif sejarah, eksisensinya hadir bersamaan dengan atau setua sejarah kelahiran peradaban manusia." Nugroho (2003: 54) mengemukakan "kebijakan publik adalah hal-hal yang diputuskan pemerintah untuk dikerjakan dan hal-hal yang diputuskan pemerintah untuk tidak dikerjakan atau dibiarkan." Pendapat yang sama dikemukakan Dye (1987: 3) "kebijakan publik merupakan pilihan apapun oleh pemerintah, baik untuk melaksanakan sesuatu maupun untuk tidak melaksanakan." Bahkan Edward dan Sharkansky dalam Islamy (1991: 18) sudah 
menegaskan "kebijakan publik adalah apa yang dikatakan dan dilakukan oleh pemerintah atau tidak dilakukan."

Dalam praktinya, kebijakan publik bukan hanya urusan pemerintah pusat atau lembaga kepresidenan melainkan lembaga atau badan-badan dan pejabat pemerintah sebagaimana dinyatakan Anderson dalam Islami (2004: 19) bahwa "kebijakan publik adalah kebijaksanaan yang dikembangkan oleh badanbadan dan pejabat-pejabat pemerintah." Hal ini dapat dipahami karena dalam system birokrasi di mana pun selalu ada pendelagasian kewenangan. Satu hal yang penting adalah kebijakan publik diputuskan dalam rangka memecahkan masalah. Chandler dan Plano dalam Kadji (2008: 8) menyatakan "kebijakan publik adalah pemanfaatan yang strategis terhadap sumber dayasumber daya yang ada untuk memecahkan masalah-masalah publik atau pemerintah." Dengan demikian, sebuah kebijakan publik tidak fungsional jika tidak mampu memecahkan masalah publik. Untuk mengetahui efektivitas kebijakan publik mengatasi permasalahan yang dihadapi pemerintah, maka diperlukan implementasikan kebijakan.

\section{Implementasi Kebijakan}

Salusu (1996: 409) menyatakan "implementasi adalah seperangkat kegiatan yang dilakukan menyusul suatu keputusan." Dalam proses pengambilan keputusan sampai penilaian keputusan, implementasi berada diantaranya. Hal ini sangat jelas merujuk pernyataan Dunn (2007: 10-11) yang mengemukakan "tahap-tahap dalam proses pembuatan kebijakan sebagai berikut: fase perumusan agenda, fase formulasi kebijakan, adopasi kebijakan, implementasi kebijakan, dan penilaian kebijakan."

Edwards III dalam Winarno (2007: 174) menegaskan "implementasi kebijakan adalah salah satu tahap kebijakan 
publik, antara pembentukan kebijakan dan konsekuensikonsekuensi bagi masyarakat yang dipengaruhinya." Wahab (2001: 45) menyatakan "pelaksanaan kebijakan adalah sesuatu yang penting bahkan jauh lebih penting daripada pembuatan kebijakan. Kebijakan-kebijakan akan sekadar impian atau rencana bagus yang tersimpan rapi dalam arsip kalau tidak diimplementasikan." Sementara itu, Dunn (2003: 80) memformulasikan "implementasi kebijakan adalah pelaksanaan dan pengendalian arah tindakan kebijakan sampai tercapainya hasil kebijakan." Sementara itu, Nugroho (2003: 158) berpendapat "implementasi kebijakan pada prinsipnya adalah cara agar sebuah kebijakan dapat mencapai tujuannya"

Dalam implementasi kebijakan dikenal beberapa model. Seperti; model George Edwards III, model Meter dan Horn, model Mazmanian dan Sabatier, model Hoogwood dan Gun, model Grindle, model Elmore, Lipsky, Hjem \& O'Porter, model Warwic, model Ripley dan Franklin, dan model Charles O. Jones. Penelitian ini menggunakan model Edwards III (1980: 148) yang dikenal beraliran top down dan dinamakan pula sebagai model direct and direct impact on implementation. Dalam bentuk bagan dapat digambarkan sebagai berikut

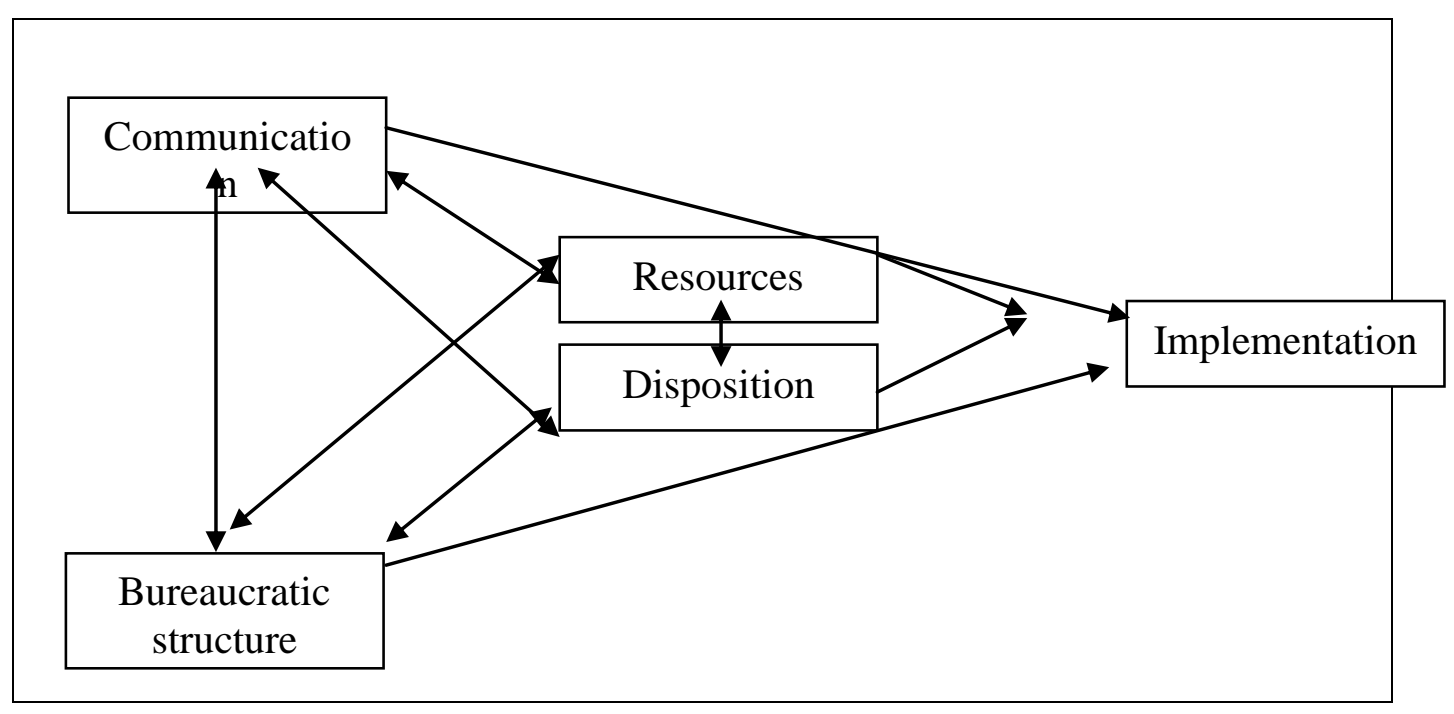


Gambar 1 : Model Implementasi Kebijakan menurut Edwards III Berdasarkan Gambar 1. Dapat dijelaskan bahwa implementasi kebijakan model Edwards III dalam Subarsono (2005: 90) dipengaruhi empat variabel yaitu "komunikasi (communication), sumber daya (resources), disposisi (disposition), dan struktur birokrasi (bureaucratic structure)."

\section{Tunjangan profesi Guru}

Muslich (2007: 3) menjelaskan bahwa "guru yang mempunyai sertifikat pendidik dianggap sebagai guru yang profesional. Yang bersangkutan mendapatkan tunjangan profesi dari pemerintah sebesar satu kali gaji pokok." Oleh karena itu, secara sistematis kajian selanjutnya yang perlu dijelaskan adalah apakah yang dimaksud tunjangan profesi guru.? Untuk menjelaskan pertanyaan tersebut, maka rujukan awal yang perlu dikemukakan adalah PP No. 41/2009 tentang Guru dan Dosen

Pasal 1 ayat 4 menjelaskan bahwa "tunjangan profesi adalah tunjangan yang diberikan kepada guru dan dosen yang memiliki sertifikat pendidik sebagai penghargaan atas profesionalitasnya." Lebih lanjut dalam regulasi yang sama pada pasal 16 dinyatakan dengan tegas bahwa "pemerintah akan memberikan tunjangan profesi kepada guru yang besarnya setara dengan 1 (satu) kali gaji pokok pada tingkat, masa kerja dan kualifikasi yang sama." Jadi tunjangan profesi guru merupakan salah satu bentuk penghargaan dan apresiasi pemerintah terhadap keberadaan guru. Wujud tunjangan profesi dimaksud adalah penambahan pendapatan guru.

Tentu saja tidak mudah mendapat tunjangan profesi guru karena harus menjadi guru profesional terlebih dahulu ditandai adanya sertifikat pendidik. Hal yang menarik dianalisis terkait tunjangan profesi guru adalah bahwa secara eksplisit telah diakui 
guru merupakan suatu profesi. Menurut Asmani (2011: 24) profesi adalah suatu "keahlian (skill) atau kewenangan dalam satu jabatan tertentu yang mensyaratkan kompetensi (pengetahuan, sikap, dan keterampilan) khusus yang diperoleh dari pendidikan akademis yang intensif." Lebih spesifik dikemukakan bahwa bidang keguruan mempunyai ciri-ciri khusus sehingga disebut sebagai profesi. Menurut Robert W. Rickey dalam Satori, dkk (2003: 19) ciri-ciri profesi keguruan sebagai berikut: (1) bahwa para guru akan bekerja hanya semata-mata memberikan pelayanan kemanusiaan daripada usaha untuk kepentingan pribadi; (2) bahwa para guru secara hukum dituntut untuk memenuhi berbagai persyaratan untuk mendapatkan lisensi mengajar serta persyaratan yang ketat untuk menjadi anggota organisasi guru; (3) bahwa para guru dituntut memiliki pemahaman serta keterampilan yang tinggi dalam hal bahan ajar, metode, anak didik dan landasan kependidikan; (4) bahwa para guru dalam organisasi profesional yang dapat melayani para guru sehingga tidak ketinggalan, bahkan selalu mengikuti perkembangan yang terjadi; (5) bahwa para guru selalu diusahakan untuk selalu mengikuti kursus-kursus, workshop, seminar, konvensi serta terlibat secara luas dalam berbagai kegiatan in service; (6) bahwa para guru diakui sepenuhnya sebagai suatu karir hidup (a life career); (7) bahwa para guru memiliki nilai dan etika yang berfungsi secara nasional maupun secara lokal.

Untuk memperkuat kajian teoritis di atas, dikemukakan pula pandangan Mohammad Ali dalam Usman (2007: 15) bahwa syarat profesi keguruan adalah (1) menuntut adanya keterampilan yang berdasarkan konsep dan teori ilmu pengetahuan yang mendalam; (2) menekankan pada suatu keahlian dalam bidang tertentu sesuai 
dengan bidang profesinya; (3) menuntut adanya tingkat pendidikan keguruan yang memadai; (4) adanya kepekaan terhadap dampak kemasyarakatan dari pekerjaan yang dilaksanakannya; 5 memungkinkan perkembangan sejalan denধ dinamika kehidupan

\section{Metode Penelitian}

Penelitian ini menggunakan paradigma penelitian kualitatif yakni penelitian yang berusaha menggambarkan data apa adanya untuk menjawab pertanyaan penelitian. Menurut Sugiono (2007.b: 49) bahwa "dalam penelitian kualitatif tidak mengenal istilah populasi tetapi oleh Spradley dinamakan "social situation" atau situasi sosial yang terdiri atas tiga elemen yaitu; tempat (place), pelaku (actors), dan aktivitas (activity) yang berinteraksi secara sinergis. Penelitian ini dilaksanakan di SMA Negeri 1 Palu dengan informan berjumlah 12 orang. Secara lengkap subjek atau actors yang dipilih dalam penelitian ini dapat disajikan sebagai berikut: Kepala Dinas Pendidikan Kota Palu, Kepala sekolah, dan pengawas Pembina, serta guru berjumlah 12 orang.

Ada dua variabel yang perlu dijadikan sasaran pengumpulan data dalam penelitian ini, yaitu: (1) Implementasi kebijakan adalah implementasi kebijakan adalah pelaksanaan kebijakan tunjangan profesi guru yang ditinjau dari empat variabel yakni; komunikasi, sumber daya, disposisi, dan struktur birokarasi dan (2) Tunjangan profesi adalah tunjangan profesi adalah tunjangan yang diberikan kepada guru yang memiliki sertifikat pendidik sebagai penghargaan atas profesionalitasnya. Tunjangan profesi guru merupakan salah satu bentuk penghargaan dan apresiasi pemerintah terhadap keberadaan guru. Wujud tunjangan profesi dimaksud adalah penambahan pendapatan guru sebesar satu kali gaji pokok. 
Penelitian ini menggunakan sumber data berupa data primer adalah data yang diperoleh secara langsung dari sumbernya dan belum diolah oleh orang lain sesuai kepentingan dan permasalahan penelitian dan data sekunder adalah data yang diperoleh dari pihak kedua atau data yang diperoleh secara tidak langsung karena sudah diolah dan disajikan oleh pihak lain sesuai kepentingan dan permasalahan penelitian.

Terkait dengan teknik pengumpulan data, penelitian ini menggunakan beberapa teknik, yakni: Wawancara, observasi, dan dokumentasi. Adapun teknik analisis yang digunakan dalam penelitian ini adalah analisis kualitatif yakni analisis data model Miles dan Huberman yang disebut analisis data model interaktif yang terdiri atas tiga tahap, yakni; reduksi data, display data, dan konklusi/verifikasi atau penarikan kesimpulan.

\section{Hasil Penelitian dan Pembahasan Implementasi Kebijakan}

Sesuai Edward III bahwa implementasi kebijakan dipengaruhi oleh empat variabel utama yakni; (1) komunikasi (communication); (2) sumber daya (resources); (3) disposisi (disposition); dan (4) struktur birokrasi (bureaucratic structure), maka untuk mengetahui implementasi keempat variabel di atas, harus dijabarkan ke dalam beberapa dimensi dan indikator yang lebih spesifik.

\section{Komunikasi}

Implementasi kebijakan ditinjau dari variabel komunikasi dengan seluruh dimensi dan indikatornya berjalan dengan baik. Dari dimensi transmisi seluruh indikator terpenuhi. Secara kognitif kebijakan sertifikasi guru dan pemberian tunjangan profesi guru telah diketahui semua stakeholder pendidikan di SMAN 1 Palu. Meskipun secara kognitif, informasi dan 
pengetahuan tentang kebijakan sertifikasi guru sudah merata akan tetapi tetap berbeda dalam tingkat pemahaman. Dapat dipastikan pemahaman kepala sekolah berbeda dengan staf. Pemahaman antar guru yang sudah mendapat tunjangan profesi guru akan berbeda dengan guru yang belum atau baru mengajukan permohonon mengikuti sertifikasi guru. Akan tetapi satu hal pasti, kebijakan tunjangan profesi guru sudah diketahui secara umum di kalangan SMAN 1 Palu. Kenyataan ini merupakan modal besar yang memperlancar implementasi kebijakan tunjangan profesi guru karena tanpa pengetahuan yang memadai tentang mekanisme kebijakan tunjangan profesi guru dengan seluruh persyaratan yang menyertainya, maka kebijakan tersebut tidak mungkin akan terlaksana dengan baik.

\section{Sumber Daya}

Berdasarkan data variabel sumber daya, maka untuk menganalisis lebih lanjut perlu dipertegas bahwa dari dua dimensi sumber daya yakni manusia dan sarana ternyata untuk sarana tidak ada masalah karena ketersediaan sarana berupa komputer sudah memadai maupun perangkat administrasi lainnya. Untuk manusia dalam hal ini pengelola atau staf yang diberikan tugas menangani administrasi guru terkait dengan tunjangan profesi guru, dari tiga indikator maka dua diantaranya sudah baik yakni jumlah pengelola dan kompetensi IT pengelola sedangkan satu indikator yakni kemampuan staf pengelola dalam menjabarkan petunjuk kepala sekolah masih perlu ditingkatkan karena masih terkesan menunggu perintah dan belum ada inisiatif sendiri untuk proaktif menangani administrasi yang bermasalah atau berkas guru yang belum lengkap untuk pengusulan sertifikasi guru. 


\section{Disposisi}

Disposisi kepala sekolah dalam mengimplementasikan kebijakan tunjangan profesi guru dari sisi internal dapat dijelaskan bahwa "kepala sekolah menilai pemberian tunjangan profesi guru sangat positif dalam pengertian dapat meningkatkan kesejahteraan guru sekaligus meningkatkan SDM. Oleh karena itu, selaku kepala sekolah senantiasa memberikan motivasi kepada staf dan guru dalam rangka memperlancar proses administrasi pemberian tunjangan profesi" (Wawancara dengan Abdul Chair pada tanggal 2 Desember 2011 di SMAN 1 Palu).

Disposisi kepala sekolah terhadap kebijakan tunjangan profesi guru secara internal sejalan dengan penilaian eksternal (penilaian dari guru dan pengawas). Data yang dikemukakan pengawas menjelaskan "semua kelengkapan administrasi yang sudah disiapkan oleh staf pengelola, selanjutnya diperiksa dan ditandatangani oleh kepala sekolah kemudian diketahui pengawas Pembina." (Wawancara dengan Andi Simpursiah pada tanggal 1 Desember 2011 di Dinas Pendidikan Kota Palu). Demikian pula data yang dikemukakan guru bahwa "kepala sekolah sudah menunjukkan sikap tanggap dan peduli terhadap kepentingan guru untuk mengikuti sertifikasi guru" (Wawancara dengan Subagia pada tanggal 2 Desember 2011).

Mencermati dan menganalisis data yang telah dikemukakan di atas, maka secara tegas dinyatakan bahwa dimensi disposisi kepala sekolah berhasil menjadi salah satu faktor penentu kelancaran implementasi kebijakan tunjangan profesi guru. Dengan kata lain dimensi disposisi memberikan kontribusi positif terhadap kelancaran proses implementasi kebijakan tunjangan profesi guru. Indikator kelancaran implementasi tunjangan profesi guru dari perspektif disposisi secara keseluruhan dapat 
diformulasikan menjadi dua aspek yakni kepala sekolah memiliki sikap inisiatif dan responsif antisipatif. Kedua kata kunci ini menjadi penentu kelancaran implementasi kebijakan tunjangan profesi guru dari perspektif disposis.

Sikap inisiatif kepala sekolah antara lain dicirikan adanya motivasi yang diberikan kepala sekolah kepada guru yang mengikuti seleksi sertifikasi untuk secara cepat dan tepat membenahi proses administrasi kelengkapan berkas pengusulan calon guru tersertifikasi. Demikian pula pada staf pengelola administrasi senantiasa mendapat pengarahan dan bimbingan dari kepala sekolah untuk aktif menyelesaikan proses administrasi guru yang menerima tunjangan sertifikasi guru maupun pengusulan untuk mengikuti seleksi sertifikasi guru. Kepala sekolah senantiasa menunjukkan sikap proaktif mempertanyakan dan mengarahkan guru yang mengalami kendala administrasi pengusulan sertifikasi maupun perpanjangan penerimaan tunjangan profesi guru. Kepala sekolah sebagai pengambil kebijakan di satuan pendidikan diharapkan proaktif untuk mendorong staf pengelola untuk dapat menjemput bola karena salah satu kelemahan pengelola adalah menunggu bola. agar keterlambatan administrasi dapat teratasi kepala sekolah dapat menegur langsung atau dengan cara pembinaan yang intensif kepada pengelola, atau mengambil sikap untuk mendelegasikan tugas dan tanggung jawab kepada KTU. (Wawancara dengan Abdul Chair pada tanggal 9 Maret 2012 di dinas pendidikan kota Palu).

Selain ciri di atas, adanya perilaku inisiatif kepala sekolah juga ditandai dengan kesungguhan kepala sekolah memeriksa dan menandatangani berkas guru untuk sertifikasi. Prinsip yang digunakan adalah tidak boleh terlambat menyelesaikan administrasi guru yang mengusul sertifikasi dan perpanjangan 
tunjangan profesi guru. Sementara itu, sikap responsif-antisipatif dimaksudkan sebagai kemampuan kepala sekolah menunjukkan sikap dan kreativitas mengatasi masalah yang mungkin muncul terkait dengan proses administrasi yang dilakukan guru ketika mengikuti seleksi sertifikasi terutama pada fase PLPG.

\section{Struktur Birokrasi}

Struktur birokrasi merupakan bagian dari variabel implementasi kebijakan. variabel struktur birokrasi dalam kerangka teoretis Edward III ternyata telah dikembangkan dalam suatu sistem koordinasi dengan melibatkan beberapa stakeholder yaitu; Dinas Pendidikan Provinsi Sulawesi Tengah, Dinas Pendidikan Kota Palu, Universitas Tadulako, dan LPMP. Keempat institusi ini bekerja secara koordinatif sehingga tidak dapat dinilai sebagai sebuah mekanisme yang bersifat hirarkis. Dinas Pendidikan Provinsi Sulawesi Tengah tidak membawahi Universitas Tadulako, LPMP, maupun Dinas Pendidikan Kota (dalam konteks sertifikasi) dan demikian pula sebaliknya. Sebenarnya jika ditelaah lebih spesifik, maka dapat ditegaskan bahwa satuan pendidikan dalam hal ini SMAN 1 Palu masuk dalam kategori alur koordinasi tersebut bahkan SMAN 1 Palu merupakan sumber awal pengadministrasian berkas tunjangan sertifikasi guru.

Secara keseluruhan struktur birokarasi dalam kaitannya dengan kebijakan tunjangan sertifikasi guru sudah dikelola secara koordinatif. Dalam pengertian seluruh unit yang terlibat dalam proses administrasi tunjangan profesi guru sudah melaksanakan tugas dan berkoordinasi satu sama lain. Akan tetapi, jika dianalisis lebih jauh, maka tidak dapat dielakkan bahwa masih ditemukan beberapa keterbatasan yakni secara birokrasi kecepatan dan ketepatan pengelolaan administrasi pemberian 
tunjangan profesi guru masih perlu ditingkatkan karena pengiriman berkas-berkas guru ke Dinas Pendidikan seringkali terlambat. Keterlambatan ini disebabkan dua faktor yakni; faktor guru yang terlambat memasukkan berkas dan faktor keterbatasan kemampuan pengelola (cenderung menunggu) sebagaimana telah dijelaskan pada variabel sumber daya.

\section{Faktor penghambat}

Menjawab permasalahan faktor apakah yang menghambat implementasi kebijakan tunjangan profesi guru? Maka terlebih dahulu dipetakan menjadi dua aspek, yakni aspek penghambat implementasi kebijakan dan aspek penghambat kebijakan pemberian tunjangan profesi guru. Faktor penghambat implementasi kebijakan pemberian tunjangan profesi guru secara kuantitatif tidak banyak. Penelitian ini berhasil mencatat dua faktor yang dapat dikedepankan, yakni; faktor masih ditemukannya keterlambatan pengiriman berkas pengusulan sertifikasi guru dan faktor keterlambatan pencairan dana tunjangan profesi guru.

Jika temuan ini dianalisis lebih dalam maka dapat dinyatakan bahwa faktor yang pertama dapat dikategorikan sebagai faktor yang muncul dari internal satuan pendidikan sedangkan faktor yang kedua tidak sepenuhnya merefleksikan kondisi internal satuan pendidikan karena bagaimanapun juga keterlambatan pencairan dana sertifikasi bersifat kompleks karena berkaitan dengan institusi lain. Dengan kata lain secara administrasi kebijakan pencairan dana sertifikasi guru berada pada level pusat, provinsi, dan dinas pendidikan termasuk unsur perbankan (bank). 


\section{Simpulan}

1. Implementasi kebijakan tunjangan profesi guru di SMA Negeri 1 Palu berjalan dengan baik. Berdasarkan model implementasi kebijakan Edward III yang terdiri atas empat variabel yakni komunikasi, sumber daya, disposisi, dan struktur birokrasi, maka hanya sumber daya pada dimensi staf pengelola belum mampu menjabarkan petunjuk kepala sekolah dan struktur birokrasi pada dimensi kecepatan dan ketepatan pengiriman berkas yang masih perlu ditingkatkan.

2. Faktor penghambat implementasi kebijakan tunjangan profesi guru adalah kecenderungan staf pengelola menunggu perintah dan kurang inisiatif. Sementara itu hambatan meningkatkan kinerja guru adalah; kemalasan, mentalitas, kurang kreatif, cepat merasa puas dengan hasil yang telah dicapai terutama hasil pembelajaran, dan guru belum konsisten memanfaatkan tunjangan profesi guru untuk peningkatan kinerja dan kompetensi guru.

\section{Saran}

1. Kepala sekolah perlu meningkatkan kualitas staf dalam mengelola administrasi guru yang mengajukan sertifikasi guru atau tunjangan profesi guru.

2. Guru perlu meningkatkan kinerja pasca tunjangan profesi guru pada aspek melakukan analisis ulangan dan tindak lanjut hasil ulangan khususnya pengayaan serta meningkatkan kualitas pembelajaran.

3. Dinas pendidikan Kota Palu diharapkan dapat memberikan pembinaan kepada staf yang masih berpikir negatif, berkeinginan untuk mengabdi kepada masyarakat dan memiliki kepedulian untuk meningkatkan mutu pendidikan. 


\section{DAFTAR PUSTAKA}

Alma, Buchari. Dkk. 2008. Guru Profesional Menguasai Metode dan Terampil Mengajar. Bandung: Alfabeta.

Asmani, Jamal Ma'mur. 2011. Tips sukses PLPG Pendidikan dan Latihan Profesi Guru. Yogyakarta: Diva Press.

Budiman, Arif. 1997. Teori Negara; Negara Kekuasaan dan Ideologi, Jakarta: Gramedia Pustaka Utama

Dye, Thomas. R. 1978. Understanding public policy. New Jersy: Englewod Cliffs Pranctice Hall.

Dunn, William, N. 2007. Analisis Kebijakan. Jakarta: Elex Media Komputindo.

2003. Pengantar Analisis Kebijakan Publik. Yogyakarta: Gadjah Mada University Press.

Edi, Suharto. 2005. Analisis Kebijakan Publik Panduan Praktis Mengkaji Masalah dan Kebijakan Sosial. Bandung: Alfabeta.

Edward III, George. C. 1980. Implementing Pablic Policy. Washington: Congressional Quarterly Press.

Islami, Irfan. 1991. Prinsip-prinsip Perumusan Kebijaksanaan Negara. Jakarta: Bumi Aksara

Kadji, Yulianto. 2008. Implementasi Kebijakan Publik Dalam Perspektif Realitas.

Khoiri, Hoyyima. 2010. Jitu dan Mudah Lulus Sertifikasi.Yogyakarta: - 76

Muslich, Masnur. 2007. Sertifikasi Guru Menuju Profesionalisme Pendidik. Jakarta: Bumi Aksara.

Nugroho, D. Riant. 2003. Kebijakan Publik: Formulasi, Implementasi, dan Evaluasi. Jakarta: Elex Media Komputindo

Salusu, J. 1996. Pengambilan Keputusan Strategik Untuk Organisasi Publik dan Organisasi Nonprofit. Jakarta: Arcan 
JIPSINDO No. 1, Volume 1, Maret 2014

Subarsono. 2008. Analisis Kebijakan Publik, Konsep Teori dan Aplikasi. Yogyakarta: Pustaka Pelajar

Sugiyono. 2007.a. Metode Penelitian Administrasi. Bandung: Alfabeta.

2007.b. Memahami Penelitian Kualitatif. Bandung: Alfabeta.

Wahab, Solihin Abdul. 2001. Analisis Kebijaksanaan: Dari Formulasi ke Implementasi Kebijaksanaan Negara. Jakarta: Bumi Aksara

Wibawa, Samudra. 1994. Kebijaksanaan Publik Proses dan Analisis. Jakarta: Intermedia.

Winarno, Budi. 2008. Kebijakan Publik, Teori, dan Proses. Jakarta: Buku Kita.

Undang-Undang No 14 Tahun 2005 tentang Guru dan Dosen

Peraturan Pemerintah Nomor 41 Tahun 2009 tentang Tunjangan Profesi Guru dan Dosen, Tunjangan Khusus Guru dan Dosen, Serta Tunjangan Kehormatan Profesor

Peraturan Menteri Pendayagunaan Aparatur Negara dan Reformasi Birokrasi Nomor 16 Tahun 2009 tentang Jabatan Fungsional Guru dan Angka Kreditnya

Peraturan Menteri Pendidikan Nasional Nomor 18 Tahun 2007 tentang Sertifikasi bagi Guru dalam Jabatan 